JURNAL AL BAYAN: JURNAL JURUSAN PENDIDIKAN BAHASA ARAB

p-ISSN 2086-9282 | e-ISSN 2549-1229

\title{
The Students' Perspective Towards YouTube as the Replacement of Lecturer in Nahwu Learning
}

\author{
Marsiah $^{1}$, Mahfuz Rizqi Mubarak ${ }^{* 2}$, Noor Amalina Audina ${ }^{3}$ \\ ${ }^{1}$ Arabic Education Study Program Institut Agama Islam Negeri Palangka Raya, Indonesia \\ ${ }^{2}$ Arabic Education Study Program Institut Agama Islam Negeri Palangka Raya, Indonesia \\ ${ }^{3}$ Master of Arabic Education Study Program Universitas Islam Negeri Maulana Malik Ibrahim Malang, \\ Indonesia
}

Article History:

Received : March 02, 2020

Revised : April 05, 2020

Accepted : May 02, 2020

Published : December 01, 2021

Keywords:

Negative Perception; Nahwu

Learning; Student's Perspective;

YouTube

*Correspondence Address: mahfuzrizqimubarak@iainpalangkaraya.ac.id

\begin{abstract}
The existence of YouTube social media as a medium to support the Arabic learning process has been widely discussed by researchers. However, the existence of this media has the potential for misunderstanding of educators in implementing YouTube as a substitute for the role of educators in the learning process. This article aims to explore students' perspectives regarding the phenomenon of misunderstanding in Nahwu science learning and recommendations so that the lecture process can run effectively. Narrative approach was used in this research. The research data were obtained from interviews with 32 students from various districts in Central Kalimantan Province. From the results of the study, it was found that students gave positive and negative perceptions about Nahwu science learning using the YouTube media. However, negative perceptions dominate more with various expressions of disappointment from students. The students definitely felt aggrieved by the implementation of the Nahwu lecture which was limited to using the YouTube media without being accompanied by further explanations from the lecturers who taught the Nahwu course. Students recommend lecturers to be more involved in the Nahwu lecture process rather than simply sharing video material that is already available on YouTube media.
\end{abstract}

\section{Introduction}

The Corona Virus Disease (COVID-19) pandemic has given a change to the world of education ${ }^{1}$. The learning process, which is used to be carried out face-to-face in a room (offline), has turned into a distance learning (online) which emphasizes the use of information technology and networks in the form of the internet ${ }^{2}$. Almost all universities

${ }^{1}$ Karwati Putu Latief, “Arti Lockdown, Social Distancing dan Istilah Populer Seputar Virus Corona," Harapan Rakyat Online (blog), March 15, 2020, https://www.harapanrakyat.com/2020/03/artilockdown-social-distancing-dan-istilah-populer-seputar-virus-corona/.

2 Esteve Corbera et al., "Academia in the Time of COVID-19: Towards an Ethics of Care," Planning Theory \& Practice 21, no. 2 (March 14, 2020): 191-99, https://doi.org/10.1080/14649357.2020.1757891; Saida Affouneh, Soheil Salha, and Zuheir N. Khlaif, 
in the world use a virtual system for the learning activities by applying several synchronous media such as Zoom Cloud Meeting ${ }^{3}$, Google Meet ${ }^{4}$, and Whatsapp ${ }^{5}$ and asynchronous media such as Google Classroom ${ }^{6}$, Edmodo $^{7}$, and Moodle ${ }^{8}$, in order to avoid physical and social contact between individuals as an effort to prevent the transmission of COVID-199.

In addition, this case was also found in one of the universities in Central Kalimantan Province which used YouTube media in Arabic learning, especially in Nahwu course. As we know, Nahwu is one of the courses which is considered as a diffcult lesson to be understood by the students ${ }^{10}$. In Hakim's research, it stated that Nahwu course material was considered something difficult and tiring to study ${ }^{11}$.

"Designing Quality E-Learning Environments for Emergency Remote Teaching in Coronavirus Crisis," Interdisciplinary Journal of Virtual Learning in Medical Sciences 11, no. 2 (June 1, 2020): 135-37, https://doi.org/10.30476/ijvlms.2020.86120.1033; Lauren S. Schlesselman, "Perspective from a Teaching and Learning Center during Emergency Remote Teaching," American Journal of Pharmaceutical Education, May 15, 2020, https://doi.org/10.5688/ajpe8142; Benjamin Luke Moorhouse, "Adaptations to a Face-to-Face Initial Teacher Education Course 'Forced' Online Due to the COVID-19 Pandemic," Journal of Education for Teaching 0, no. 0 (April 15, 2020): 1-3, https://doi.org/10.1080/02607476.2020.1755205; Hani Morgan, "Best Practices for Implementing Remote Learning during a Pandemic," The Clearing House: A Journal of Educational Strategies, Issues and Ideas 93, no. 3 (May 3, 2020): 135-41, https://doi.org/10.1080/00098655.2020.1751480; Michael P. A. Murphy, "COVID-19 and Emergency ELearning: Consequences of the Securitization of Higher Education for Post-Pandemic Pedagogy," Contemporary Security Policy 41, no. 3 (July 2, 2020): 492-505, https://doi.org/10.1080/13523260.2020.1761749.

${ }^{3}$ Mahfuz Rizqi Mubarak et al., "Zoom Cloud Meeting: Media Alternatif dalam Pembelajaran Maharah Kalam di Tengah Wabah Virus Corona (Covid-19)," Arabiyatuna: Jurnal Bahasa Arab 4, no. 2 (November 17, 2020): 211-26, https://doi.org/10.29240/jba.v4i2.1445.

${ }^{4}$ Rana Saeed Al-Maroof et al., "Fear from COVID-19 and Technology Adoption: The Impact of Google Meet during Coronavirus Pandemic," Interactive Learning Environments 0, no. 0 (October 14, 2020): 1-16, https://doi.org/10.1080/10494820.2020.1830121.

${ }^{5}$ Aulia Mustika Ilmiani et al., "Whatsapp Group to Optimize the Mahārah Istimā' Learning During the Covid-19 Pandemic," ALSINATUNA 6, no. 1 (December 14, 2020): 16-34, https://doi.org/10.28918/alsinatuna.v6i1.2841.

${ }^{6}$ Mike Okmawati, "The Use of Google Classroom during Pandemic," Journal of English Language Teaching 9, no. 2 (August 11, 2020): 438-443-443, https://doi.org/10.24036/jelt.v9i2.109293.

7 Ervan Johan Wicaksana et al., "Edmodo as a Solution to Enhance Student Learning Interest in High School Biodiversity during the COVID-19 Pandemic," Biosfer: Jurnal Pendidikan Biologi 13, no. 2 (October 22, 2020): 216-29, https://doi.org/10.21009/biosferjpb.v13n2.216-229.

${ }^{8}$ Like Raskova Octaberlina and Afif Ikhwanul Muslimin, "EFL Students Perspective towards

Online Learning Barriers and Alternatives Using Moodle/Google Classroom during COVID-19 Pandemic," International Journal of Higher Education 9, no. 6 (August 10, 2020): 1, https://doi.org/10.5430/ijhe.v9n6p1.

${ }^{9}$ David M. Erekson et al., "Responding to the Covid-19 Pandemic at a University Counseling Center: Administrative Actions, Client Retention, and Psychotherapy Outcome," Counselling Psychology Quarterly 0, no. 0 (August 17, 2020): 1-15, https://doi.org/10.1080/09515070.2020.1807914.

${ }^{10}$ Zam Zam Rasyidi, "Pembelajaran Qawaid: Perspektif Teori Kognitif Pada Pondok Pesantren Raudhatut Thalibin Kalimantan Selatan," Al-Ta'rib: Jurnal Ilmiah Program Studi Pendidikan Bahasa Arab IAIN Palangka Raya 8, no. 1 (June 24, 2020): 103-16, https://doi.org/10.23971/altarib.v8i1.1865.

${ }^{11}$ Arif Rahman Hakim, "Mempermudah Pembelajaran Ilmu Nahwu Pada Abad 20," Jurnal Al Maqayis 1, no. 1 (September 2, 2014), https://doi.org/10.18592/jams.v1i1.96. 
However, the problem is the lecturers who teach the subject merely share the link of Nahwu material via WhatsApp which is available on YouTube without any further explanation regarding the results of the video material that has been shared. This is certainly contradictory to the duties and obligations of an educator. An educator is the spearhead in improving the quality of education. The educator in the classroom has an important role in motivating students to achieve educational goals, which is to develop the nation's intelectual life $\mathrm{e}^{12}$. The support from an educator implies the satisfaction with the students ${ }^{13}$. The physical presence of an educator has an irreplaceable role in developing the students' characters ${ }^{14}$.

Several previous research explained that some educators used YouTube as an alternative in implementing online learning ${ }^{15}$. The existence of YouTube media in the world of education is proven to help improve students' abilities in the aspects of foreign language learning ${ }^{16}$. There is even an adage "You can learn anything on YouTube" ${ }^{17}$. This is because YouTube can produce more flexible, interesting, and more interactive learning ${ }^{18}$. However, some of the studies above show that the existence of successful YouTube media is only used as supporting media in the learning process, not replacing

${ }^{12}$ Ahmad Idzhar, "Peranan Guru Dalam Meningkatkan Motivasi Belajar Siswa," Jurnal Office 2, no. 2 (December 31, 2016): 221-28, https://doi.org/10.26858/jo.v2i2.2956.

${ }^{13}$ Michael T. Geier, "Students' Expectations and Students' Satisfaction: The Mediating Role of Excellent Teacher Behaviors," Teaching of Psychology 48, no. 1 (January 1, 2021): 9-17, https://doi.org/10.1177/0098628320959923.

${ }^{14}$ Cathrine V. Felix, "The Role of the Teacher and AI in Education," in International Perspectives on the Role of Technology in Humanizing Higher Education, ed. Enakshi Sengupta, Patrick Blessinger, and Mandla S. Makhanya, vol. 33, Innovations in Higher Education Teaching and Learning (Emerald Publishing Limited, 2020), 33-48, https://doi.org/10.1108/S2055-364120200000033003.

${ }^{15}$ R. El A. Ghobrini, "Synergizing Facebook and YouTube for E-Teaching Grammar during Covid19 Pandemic," International Journal of Education and Science 3, no. 4 (November 30, 2020): 33, https://doi.org/10.26697/ijes; Andrey Indra Ridwana Wibowo and M. Ed Fitri Kurniawan, "The Use Of YouTube As Teaching Media In Public Speaking Class: Students Perspective", Skripsi Universitas Muhammadiyah Surakarta, (2020); Lokanath Mishra, Tushar Gupta, and Abha Shree, "Online TeachingLearning in Higher Education during Lockdown Period of COVID-19 Pandemic," International Journal of Educational Research Open 1 (January 1, 2020): 100012, https://doi.org/10.1016/j.ijedro.2020.100012.

16 Hamidah Hamidah and Marsiah Marsiah, "Pembelajaran Maharah Al-Istima' Dengan Memanfaatkan Media Youtube: Problematika Dan Solusi," Al-Ta'rib: Jurnal Ilmiah Program Studi Pendidikan Bahasa Arab IAIN Palangka Raya 8, no. 2 (December 2, 2020): 147-60, https://doi.org/10.23971/altarib.v8i2.2282; Sulaila Bakar et al., "Using YouTube to Encourage English Learning in ESL Classrooms," in Proceedings of the Regional Conference on Science, Technology and Social Sciences (RCSTSS 2016), ed. Mohd Yusri Mohamad Noor et al. (Singapore: Springer, 2019), 41519, https://doi.org/10.1007/978-981-13-0203-9_38.

${ }^{17}$ Patricia G. Lange, "Informal Learning on YouTube," in The International Encyclopedia of Media Literacy (American Cancer Society, 2018), 1-11, https://doi.org/10.1002/9781118978238.ieml0090.

${ }^{18}$ Hamidah and Marsiah, "Pembelajaran Maharah Al-Istima' Dengan Memanfaatkan Media Youtube." 
the educators in the learning process, as what has happened in this discussion. This is the novelty of this study compared to the previous studies.

Therefore, the researcher took the initiative to solve this problem by analyzing the perceptions of students who had the online learning on Nahwu course by using the YouTube media. The results of this study are expected to minimize the problems that occur in the implementation of online learning, especially in the aspect of misperceptions in responding to the use of YouTube as the media for Arabic learning.

\section{Method}

Narrative research design was used in this research which is to directly explore the information from participants in order to explain the experiences and phenomena ${ }^{19}$. The use of this design is because this study focuses on the narrative of the students' perceptions in the university in Central Kalimantan Province regarding their experiences in conducting online learning, especially in Nahwu course by using the YouTube.

This study involved 32 students from several districts in Central Kalimantan Province. The 32 students were recruited based on their willingness to fill out Google Form about the participant recruitment which was distributed through the WhatsApp study group. Google Form also classified potential participants into several categories, namely: Gender, city / district origin, and latest education. The participants were also given the opportunity by the researchers to resign if they felt less pleased with this research. Thus, it is truly based on the conscience of the participants without any pressure $^{20}$.

The data collection technique was conducted by using written interviews prepared through Google Form which included students' perceptions of online learning especially in Nahwu course by using YouTube, and how lecturers should do in implementing YouTube as a media in online learning in Nahwu course.

The data analysis techniques used in this study were as follows: First, collecting data obtained from the overall interview results. Second, reducing data based on the

${ }^{19}$ D. J. Clandinin and J. Huber, "Narrative Inquiry," in International Encyclopedia of Education (Third Edition), ed. Penelope Peterson, Eva Baker, and Barry McGaw (Oxford: Elsevier, 2010), 436-41, https://doi.org/10.1016/B978-0-08-044894-7.01387-7.

${ }^{20}$ Martyn Hammersley and Anna Traianou, Ethics in Qualitative Research: Controversies and Contexts (SAGE, 2012). 
themes discussed in the study. Third, presenting data according to the themes discussed in the research. Fourth, concluding the results of the study ${ }^{21}$.

\section{Result and Discussion \\ Profile of the Students}

As what is mentioned previously, the researcher classified 32 student participants into several categories, namely: (1) Gender. Among of the 32 student participants, $87 \%$ were female and $12 \%$ were male. (2) City / regency. 32 student participants came from 7 different cities/districts such as Palangka Raya, South Barito, Gunung Mas, Center Katingan, East Kotawaringin, Maros, and Sukamara. (3) Last education. 32 student participants have a heterogeneous educational background, namely $41 \%$ SMA/SMAN alumni, 44\% MA/MAN alumni, 9\% SMK alumni, and 2\% islamic boarding school alumni. Thus, it can be concluded that the number of female students is more dominant than the number of male students. They also come from various districts/cities and have educational backgrounds dominated by MA/MAN and SMA/SMAN.

\section{Students' Perceptions Towards Online Learning on Nahwu Course by Using YouTube}

At this point, the researcher found various perceptions expressed by the students about their experiences about online learning in Nahwu course by using YouTube. The researchers divided the various perceptions into two categories, namely (1) positive perceptions, and (2) negative perceptions.

\section{Positive Perceptions}

From the results of the interview, the researcher found several positive perceptions which would be explained as follows: first, YouTube presents interesting and easy way to understand $N a h w u$ material. Students revealed that the video of Nahwu material distributed by the lecturer with the interesting presentations and the presentation was well-arranged so that it was easy to understand. This confirmed the findings of Ilmiani (2020) which reported that learning materials that were presented attractively in

${ }^{21}$ Michael Huberman and Matthew B. Miles, The Qualitative Researcher's Companion (SAGE, 2002). 
the form of interactive media had a positive impact in achieving the goals of Arabic learning ${ }^{22}$.

Second, it can be accessed anywhere and anytime. Students revealed that the material presented on YouTube had the advantages such as the flexibility to use. Students can access video material by using various gadgets such as smartphones and laptops. Students also do not worry about missing the material considering that the video presented on YouTube can be played many times. This flexibility is certainly beneficial for students' understanding of Nahwu material. As Hakim in his research emphasized that Nahwu material is difficult and overwhelming to study ${ }^{23}$. The flexibility of YouTube in the learning process was also strengthened by the results of research by Neuman \& Herodotou (2020) which revealed that YouTube media is easy to access (even for children) because it can be accessed by any digital device that is connected to the internet $\operatorname{access}^{24}$.

From the results of the explanation above, the researcher found two positive perceptions of students about Nahwu by using YouTube, namely (1) the presentation of the Nahwu material becomes interesting, and (2) the flexibility of YouTube in Nahwu learning.

\section{Negative Perceptions}

In addition, as the researcher explained in the introduction, lecturers merely shared YouTube video links about Nahwu material to the students. This eventually lead various kinds of negative responses from the students. So it is not surprising when any negative perceptions were dominated. The student' perception towards Nahwu learning by using YouTube are explained as follows: First, students revealed that the material presented through YouTube videos is difficult to understand. This is caused by the absence of the opportunity for students to ask questions directly from the lecturer. Moreover, the majority of students were from public schools where Arabic subjects are not taught there. This case strengthened the results of the research of Mukmin (2019) that

\footnotetext{
${ }^{22}$ Aulia Mustika Ilmiani et al., "Multimedia Interaktif Untuk Mengatasi Problematika Pembelajaran Bahasa Arab," Al-Ta'rib : Jurnal Ilmiah Program Studi Pendidikan Bahasa Arab IAIN Palangka Raya 8, no. 1 (June 24, 2020): 17-32, https://doi.org/10.23971/altarib.v8i1.1902.

${ }_{23}^{23}$ Hakim, "Mempermudah Pembelajaran Ilmu Nahwu Pada Abad 20".

${ }^{24}$ Michelle M. Neumann and Christothea Herodotou, "Young Children and YouTube: A Global Phenomenon," Childhood Education 96, no. 4 (July 3, 2020): 72-77, https://doi.org/10.1080/00094056.2020.1796459.
} 
the students' background about Arabic language learning has a significant effect on their results and motivation to continue learning Arabic ${ }^{25}$.

Second, students also revealed that some locations near their house has the serious problem with the internet signals. In fact, it is not uncommon when the learning process takes place, students have to travel about an hour from home to find a location that has a strong internet signal, only to download YouTube videos about Nahwu material distributed by lecturers. This finding is in line with what has been reported by Robinson and Rawlings (2018) that internet connection still becomes a serious problem in certain areas even though the majority of students are already able in applying technology ${ }^{26}$. This raises disappointment for students considering the efforts made by students are not comparable to what they get from lecturers who teach Nahwu course. This can demotivate students in learning.

Third, students do not hesitate to reveal that the way of learning they get from Nahwu course by only using YouTube is wasting their internet data plans. They revealed that the majority of videos shared by lecturers had a long duration and consumed a lot of internet data plans. They usually look for the $\mathrm{WiFi}$ corner provided by the government instead of using their own internet data plans on their cellular card.

Fourth, as previously stated, the learning system implemented by lecturers caused disappointment to students. Some students even gave the statements "why should we pay tuition fees if we only get the videos of Nahwu material from YouTube?". This statement is very natural considering the condition of the Covid-19 pandemic which is still unstoppable, and the poor quality of the learning process has an effect on student psychology 27 .

From this, it can be concluded that online learning on Nahwu course by using the YouTube have four negative perceptions such as: (1) Difficult to understand the Nahwu material from YouTube (2) Bad signal or the internet connection in several locations 3) Wasting to much internet data plans and (4) Affecting students' psychology.

25 Mukmin Mukmin, "The Effect of Educational Background and Language Competence on Students' Arabic Language Motivation," Arabiyat : Jurnal Pendidikan Bahasa Arab dan Kebahasaaraban 6, no. 1 (June 12, 2019): 36-52, https://doi.org/10.15408/a.v6i1.10484.

${ }^{26}$ Roger A. Harrison et al., "The Experience of International Postgraduate Students on a DistanceLearning Programme," Distance Education 39, no. 4 (October 2, 2018): 480-94, https://doi.org/10.1080/01587919.2018.1520038.

${ }^{27}$ Haijing Ma and Claude Miller, "Trapped in a Double Bind: Chinese Overseas Student Anxiety during the COVID-19 Pandemic," Health Communication 0, no. 0 (June 12, 2020): 1-8, https://doi.org/10.1080/10410236.2020.1775439. 


\section{Students' Recommendations towards Online Learning on Nahwu Courses Using YouTube}

To overcome the problems, students suggest some input that can be used as a reference for lecturers in online learning in Nahwu course using the YouTube media. First, students want further explanations from lecturers both through WhatsApp and Zoom. This will help students to understand the material presented. Students hope that the explanation of the advanced material does not have to start with the student's question first, but the lecturer must provide the explanation a few minutes after the YouTube video material is presented. Students also add that some of them were shy to ask questions so they preferred to be silent. Therefore, it is necessary to have a personal approach between lecturers and students by increasing interaction in the form of asking students one by one, not asking in general. Nitta and Studa (2020) in their research reported that the intensity of the interaction between educators and learners has a positive impact on the learning motivation of learners ${ }^{28}$.

Second, students hope that the material video presented has a short duration and has a brief explanation. On the other hand, students prefer material video which made by the course lecturer, not from videos which is taken from various sources. They argued that the video developed directly by the lecturer would be easier for them to understand because the lecturer who taught the course certainly the characteristics of the students in the class.

From the explanation above, the researcher concluded that no matter how sophisticated YouTube is, it will still not replace the position of educators in the process of teaching and learning activities both offline and online. Moreover, Nahwu course, which is still considered as a difficult and overwhelming subject to $\operatorname{study}^{29}$, is more identical to being taught with conventional methods popular among Islamic boarding schools $^{30}$. Researchers agree with the statement of Moghavvemi et al. (2018) that

${ }^{28}$ Yoshiyuki Nakata, Ryo Nitta, and Atsuko Tsuda, "Understanding Motivation and Classroom Modes of Regulation in Collaborative Learning: An Exploratory Study," Innovation in Language Learning and Teaching 0, no. 0 (November 26, 2020): 1-15, https://doi.org/10.1080/17501229.2020.1846040.

${ }^{29}$ Hakim, "Mempermudah Pembelajaran Ilmu Nahwu Pada Abad 20."

${ }^{30}$ Aliyah Aliyah, "Pesantren Tradisional Sebagai Basis Pembelajaran Nahwu Dan Sharaf Dengan Menggunakan Kitab Kuning," Al-Ta'rib: Jurnal Ilmiah Program Studi Pendidikan Bahasa Arab IAIN Palangka Raya 6, no. 1 (June 1, 2018): 1-25, https://doi.org/10.23971/altarib.v6i1.966. 
YouTube can be used as a complementary or supporting tool for the learning process, not to replace the educators in the learning process ${ }^{31}$.

The existence of YouTube as a learning media among learners, even more preferable than other learning sources, has indeed become an indisputable fact ${ }^{32}$. Even El Miedany (2019) in his book stated that YouTube is the second most popular website in the internet world ${ }^{33}$. As previously mentioned, YouTube site is easily accessible by anyone (even children) and has low barriers because it can be accessed through any digital device such as tablets, cellphones and laptops that are connected to the internet ${ }^{34}$. However, learning media which is produced by technological developments cannot completely replace conventional learning processes which emphasize the communication between educators and learners ${ }^{35}$. Although YouTube can produce learning that is more flexible, more interesting ${ }^{36}$, and more interactive than formal learning, YouTube is less effective in the matters of language learning. ${ }^{37}$ An educator or a teacher is still crucial and needed. Therefore, the use of YouTube media is recommended only for learning media, not to replace the role of educators in the learning process ${ }^{38}$.

The recommendation to overcome this problem as stated by the participants is to use media such as Zoom Cloud Meeting, Google Meet, and Skype. These synchronous

${ }^{31}$ Sedigheh Moghavvemi et al., "Social Media as a Complementary Learning Tool for Teaching and Learning: The Case of Youtube," The International Journal of Management Education 16, no. 1 (March 1, 2018): 37-42, https://doi.org/10.1016/j.ijme.2017.12.001.

32 Azzam Alobaid, 'Smart Multimedia Learning of ICT: Role and Impact on Language Learners' Writing Fluency - YouTube Online English Learning Resources as an Example," Smart Learning Environments 7, no. 1 (September 15, 2020): 24, https://doi.org/10.1186/s40561-020-00134-7.

33 Yasser El Miedany, "Social Media and YouTube," in Rheumatology Teaching: The Art and Science of Medical Education, ed. Yasser El Miedany (Cham: Springer International Publishing, 2019), 305-26, https://doi.org/10.1007/978-3-319-98213-7_16.

${ }^{34}$ Neumann and Herodotou, "Young Children and YouTube,"

35 Olga V. Anisimova et al., "Integration of Internet Tools to Enhance Pronunciation Skills: Effectiveness of Educational Content on YouTube," in Integrating Engineering Education and Humanities for Global Intercultural Perspectives, ed. Zhanna Anikina, Lecture Notes in Networks and Systems (Cham: Springer International Publishing, 2020), 199-211, https://doi.org/10.1007/978-3-030-47415-7_21. Youtube, "

36 Hamidah and Marsiah, "Pembelajaran Maharah Al-Istima' Dengan Memanfaatkan Media

${ }^{37}$ Hung-chun Wang and Cheryl Wei-yu Chen, "Learning English from YouTubers: English L2 Learners' Self-Regulated Language Learning on YouTube," Innovation in Language Learning and Teaching 14, no. 4 (August 7, 2020): 333-46, https://doi.org/10.1080/17501229.2019.1607356.

${ }^{38}$ Quan Zhou et al., "Understanding the Use of YouTube as a Learning Resource: A Social Cognitive Perspective," Aslib Journal of Information Management 72, no. 3 (January 1, 2020): 339-59, https://doi.org/10.1108/AJIM-10-2019-0290. 
media provide face-to-face activities and interaction between educators and students and supporting virtual videos ${ }^{39}$.

\section{Conclusion}

From the results of the research above, the researcher concluded that the case of lecturing the Nahwu course by only using YouTube video as happened above was in fact dominated by negative responses from students. Some negative perceptions such as the difficulty in understanding the material presented on YouTube videos, bad signals or internet connection, wasting the internet data plans, affecting students' psychology, and the students are not satisified with the lecture process, especially in Nahwu courses. To make Nahwu learning more effective, students recommend media that can facilitate both lecturers and students for face-to-face interactions in Nahwu learning. By learning in a conventional way with face-to-face interaction would give more positive results on the learning outcomes of Nahwu as Islamic boarding schools. Based on the results of the research above, the researcher recommends further research on students' perceptions about improving four Arabic language skills by using YouTube.

\section{Acknowledgment}

We would like to thank the participants of Arabic Education students in Central Kalimantan Province who have willingly participated and helped in the completion of this article.

\section{References}

Affouneh, Saida, Soheil Salha, and Zuheir N. Khlaif. "Designing Quality E-Learning Environments for Emergency Remote Teaching in Coronavirus Crisis." Interdisciplinary Journal of Virtual Learning in Medical Sciences 11, no. 2 (June 1, 2020): 135-37. https://doi.org/10.30476/ijvlms.2020.86120.1033.

Ahmadi, Ahmadi, and Aulia Mustika Ilmiani. "The Use of Teaching Media in Arabic Language Teaching During Covid-19 Pandemic." Dinamika Ilmu: Jurnal Pendidikan 20, no. 2 (December 1, 2020): 307-22. https://doi.org/10.21093/di.v20i2.2515.

\footnotetext{
${ }^{39}$ Mubarak et al., "Zoom Cloud Meeting"; Ahmadi Ahmadi and Aulia Mustika Ilmiani, "The Use of Teaching Media in Arabic Language Teaching During Covid-19 Pandemic," Dinamika Ilmu: Jurnal Pendidikan 20, no. 2 (December 1, 2020): 307-22, https://doi.org/10.21093/di.v20i2.2515.
} 
Aliyah, Aliyah. "Pesantren Tradisional Sebagai Basis Pembelajaran Nahwu Dan Sharaf Dengan Menggunakan Kitab Kuning." Al-Ta'rib: Jurnal Ilmiah Program Studi Pendidikan Bahasa Arab IAIN Palangka Raya 6, no. 1 (June 1, 2018): 1-25. https://doi.org/10.23971/altarib.v6i1.966.

Alobaid, Azzam. "Smart Multimedia Learning of ICT: Role and Impact on Language Learners' Writing Fluency - YouTube Online English Learning Resources as an Example." Smart Learning Environments 7, no. 1 (September 15, 2020): 24. https://doi.org/10.1186/s40561-020-00134-7.

Anisimova, Olga V., Lola K. Bobodzhanova, Kseniya S. Kolobova, and Inna S. Makarova. "Integration of Internet Tools to Enhance Pronunciation Skills: Effectiveness of Educational Content on YouTube." In Integrating Engineering Education and Humanities for Global Intercultural Perspectives, edited by Zhanna Anikina, 199-211. Lecture Notes in Networks and Systems. Cham: Springer International Publishing, 2020. https://doi.org/10.1007/978-3-030-47415-7_21.

Bakar, Sulaila, Rosita Aminullah, Jun Nirlawati Mohd Sahidol, Nik Ismail Harun, and Azlini Razali. "Using YouTube to Encourage English Learning in ESL Classrooms." In Proceedings of the Regional Conference on Science, Technology and Social Sciences (RCSTSS 2016), edited by Mohd Yusri Mohamad Noor, Badli Esham Ahmad, Mohd Rozaidi Ismail, Hasnizawati Hashim, and Mohd Amli Abdullah Baharum, 415-19. Singapore: Springer, 2019. https://doi.org/10.1007/978-981-13-0203-9_38.

Clandinin, D. J., and J. Huber. "Narrative Inquiry." In International Encyclopedia of Education (Third Edition), edited by Penelope Peterson, Eva Baker, and Barry McGaw, 436-41. Oxford: Elsevier, 2010. https://doi.org/10.1016/B978-0-08044894-7.01387-7.

Corbera, Esteve, Isabelle Anguelovski, Jordi Honey-Rosés, and Isabel Ruiz-Mallén. "Academia in the Time of COVID-19: Towards an Ethics of Care." Planning Theory \& Practice 21, no. 2 (March 14, 2020): 191-99. https://doi.org/10.1080/14649357.2020.1757891.

El Miedany, Yasser. "Social Media and YouTube." In Rheumatology Teaching: The Art and Science of Medical Education, edited by Yasser El Miedany, 305-26. Cham: Springer International Publishing, 2019. https://doi.org/10.1007/978-3-319-982137_16.

Erekson, David M., Russell J. Bailey, Kara Cattani, Sheilagh T. Fox, and Melissa K. Goates-Jones. "Responding to the Covid-19 Pandemic at a University Counseling Center: Administrative Actions, Client Retention, and Psychotherapy Outcome." Counselling Psychology Quarterly 0, no. 0 (August 17, 2020): 1-15. https://doi.org/10.1080/09515070.2020.1807914.

Felix, Cathrine V. "The Role of the Teacher and AI in Education." In International Perspectives on the Role of Technology in Humanizing Higher Education, edited by Enakshi Sengupta, Patrick Blessinger, and Mandla S. Makhanya, 33:33-48. 
Innovations in Higher Education Teaching and Learning. Emerald Publishing Limited, 2020. https://doi.org/10.1108/S2055-364120200000033003.

Geier, Michael T. 'Students' Expectations and Students' Satisfaction: The Mediating Role of Excellent Teacher Behaviors." Teaching of Psychology 48, no. 1 (January 1, 2021): 9-17. https://doi.org/10.1177/0098628320959923.

Ghobrini, R. El A. "Synergizing Facebook and YouTube for E-Teaching Grammar during Covid-19 Pandemic." International Journal of Education and Science 3, no. 4 (November 30, 2020): 33. https://doi.org/10.26697/ijes.

Hakim, Arif Rahman. "Mempermudah Pembelajaran Ilmu Nahwu Pada Abad 20." Jurnal Al Maqayis 1, no. 1 (September 2, 2014). https://doi.org/10.18592/jams.v1i1.96.

Hamidah, Hamidah, and Marsiah Marsiah. "Pembelajaran Maharah Al-Istima' Dengan Memanfaatkan Media YouTube: Problematika Dan Solusi." Al-Ta'rib: Jurnal Ilmiah Program Studi Pendidikan Bahasa Arab IAIN Palangka Raya 8, no. 2 (December 2, 2020): 147-60. https://doi.org/10.23971/altarib.v8i2.2282.

Hammersley, Martyn, and Anna Traianou. Ethics in Qualitative Research: Controversies and Contexts. SAGE, 2012.

Harrison, Roger A., Annie Harrison, Christine Robinson, and Barbara Rawlings. "The Experience of International Postgraduate Students on a Distance-Learning Programme." Distance Education 39, no. 4 (October 2, 2018): 480-94. https://doi.org/10.1080/01587919.2018.1520038.

Huberman, Michael, and Matthew B. Miles. The Qualitative Researcher's Companion. SAGE, 2002.

Idzhar, Ahmad. "Peranan Guru Dalam Meningkatkan Motivasi Belajar Siswa." Jurnal Office 2, no. 2 (December 31, 2016): 221-28. https://doi.org/10.26858/jo.v2i2.2956.

Ilmiani, Aulia Mustika, Ahmadi Ahmadi, Nur Fuadi Rahman, and Yulia Rahmah. "Multimedia Interaktif Untuk Mengatasi Problematika Pembelajaran Bahasa Arab." Al-Ta'rib: Jurnal Ilmiah Program Studi Pendidikan Bahasa Arab IAIN Palangka Raya 8, no. 1 (June 24, 2020): 17-32. https://doi.org/10.23971/altarib.v8i1.1902.

Ilmiani, Aulia Mustika, Marsiah Marsiah, Yulia Rahmah, and Mahfuz Rizqi Mubarak. "Whatsapp Group to Optimize the Mahārah Istimā' Learning During the Covid-19 Pandemic." ALSINATUNA 6, no. 1 (December 14, 2020): 16-34. https://doi.org/10.28918/alsinatuna.v6i1.2841.

Lange, Patricia G. "Informal Learning on YouTube." In The International Encyclopedia of Media Literacy, 1-11. American Cancer Society, 2018. https://doi.org/10.1002/9781118978238.ieml0090. 
Latief, Karwati Putu. "Arti Lockdown, Social Distancing dan Istilah Populer Seputar Virus Corona." Harapan Rakyat Online (blog), March 15, 2020. https://www.harapanrakyat.com/2020/03/arti-lockdown-social-distancing-danistilah-populer-seputar-virus-corona/.

Ma, Haijing, and Claude Miller. "Trapped in a Double Bind: Chinese Overseas Student Anxiety during the COVID-19 Pandemic." Health Communication 0, no. 0 (June 12, 2020): 1-8. https://doi.org/10.1080/10410236.2020.1775439.

Al-Maroof, Rana Saeed, Said A. Salloum, Aboul Ella Hassanien, and Khaled Shaalan. "Fear from COVID-19 and Technology Adoption: The Impact of Google Meet during Coronavirus Pandemic." Interactive Learning Environments 0, no. 0 (October 14, 2020): 1-16. https://doi.org/10.1080/10494820.2020.1830121.

Mishra, Lokanath, Tushar Gupta, and Abha Shree. "Online Teaching-Learning in Higher Education during Lockdown Period of COVID-19 Pandemic." International Journal of Educational Research Open 1 (January 1, 2020): 100012. https://doi.org/10.1016/j.ijedro.2020.100012.

Moghavvemi, Sedigheh, Ainin Sulaiman, Noor Ismawati Jaafar, and Nafisa Kasem. "Social Media as a Complementary Learning Tool for Teaching and Learning: The Case of YouTube." The International Journal of Management Education 16, no. 1 (March 1, 2018): 37-42. https://doi.org/10.1016/j.ijme.2017.12.001.

Moorhouse, Benjamin Luke. "Adaptations to a Face-to-Face Initial Teacher Education Course 'Forced' Online Due to the COVID-19 Pandemic." Journal of Education for Teaching 0 , no. 0 (April 15, 2020): 1-3. https://doi.org/10.1080/02607476.2020.1755205.

Morgan, Hani. "Best Practices for Implementing Remote Learning during a Pandemic." The Clearing House: A Journal of Educational Strategies, Issues and Ideas 93, no. 3 (May 3, 2020): 135-41. https://doi.org/10.1080/00098655.2020.1751480.

Mubarak, Mahfuz Rizqi, Nurul Wahdah, Aulia Mustika Ilmiani, and Hamidah Hamidah. "Zoom Cloud Meeting: Media Alternatif dalam Pembelajaran Maharah Kalam di Tengah Wabah Virus Corona (Covid-19)." Arabiyatuna: Jurnal Bahasa Arab 4, no. 2 (November 17, 2020): 211-26. https://doi.org/10.29240/jba.v4i2.1445.

Mukmin, Mukmin. "The Effect of Educational Background and Language Competence on Students' Arabic Language Motivation." Arabiyat: Jurnal Pendidikan Bahasa Arab Dan Kebahasaaraban 6, no. 1 (June 12, 2019): 36-52. https://doi.org/10.15408/a.v6i1.10484.

Murphy, Michael P. A. "COVID-19 and Emergency ELearning: Consequences of the Securitization of Higher Education for Post-Pandemic Pedagogy." Contemporary Security Policy 41, no. 3 (July 2, 2020): 492-505. https://doi.org/10.1080/13523260.2020.1761749.

Nakata, Yoshiyuki, Ryo Nitta, and Atsuko Tsuda. "Understanding Motivation and Classroom Modes of Regulation in Collaborative Learning: An Exploratory 
Study." Innovation in Language Learning and Teaching 0, no. 0 (November 26, 2020): 1-15. https://doi.org/10.1080/17501229.2020.1846040.

Neumann, Michelle M., and Christothea Herodotou. "Young Children and YouTube: A Global Phenomenon." Childhood Education 96, no. 4 (July 3, 2020): 72-77. https://doi.org/10.1080/00094056.2020.1796459.

Octaberlina, Like Raskova, and Afif Ikhwanul Muslimin. "EFL Students Perspective towards Online Learning Barriers and Alternatives Using Moodle/Google Classroom during COVID-19 Pandemic." International Journal of Higher Education 9, no. 6 (August 10, 2020): 1. https://doi.org/10.5430/ijhe.v9n6p1.

Okmawati, Mike. "The Use of Google Classroom during Pandemic." Journal of English Language Teaching 9, no. 2 (August 11, 2020): 438-443-443. https://doi.org/10.24036/jelt.v9i2.109293.

Rasyidi, Zam Zam. "Pembelajaran Qawaid: Perspektif Teori Kognitif Pada Pondok Pesantren Raudhatut Thalibin Kalimantan Selatan." Al-Ta'rib: Jurnal Ilmiah Program Studi Pendidikan Bahasa Arab IAIN Palangka Raya 8, no. 1 (June 24, 2020): 103-16. https://doi.org/10.23971/altarib.v8i1.1865.

Schlesselman, Lauren S. "Perspective from a Teaching and Learning Center during Emergency Remote Teaching." American Journal of Pharmaceutical Education, May 15, 2020. https://doi.org/10.5688/ajpe8142.

Wang, Hung-chun, and Cheryl Wei-yu Chen. "Learning English from YouTubers: English L2 Learners' Self-Regulated Language Learning on YouTube." Innovation in Language Learning and Teaching 14, no. 4 (August 7, 2020): 333-46. https://doi.org/10.1080/17501229.2019.1607356.

Wibowo, Andrey Indra Ridwana, and M. Ed Fitri Kurniawan. "The Use Of YouTube As Teaching Media In Public Speaking Class: Students Perspective." S1, Universitas Muhammadiyah Surakarta, 2020. https://doi.org/10/SURAT\%20PERNYATAAN\%20PUBLIKASI\%20ILMIAHdikonversi.pdf.

Wicaksana, Ervan Johan, Pramana Atmadja, W. Wikanso, Loly Nadila Putri, and Gusti Ayu Muthia. "Edmodo as a Solution to Enhance Student Learning Interest in High School Biodiversity during the COVID-19 Pandemic." Biosfer: Jurnal Pendidikan Biologi 13, no. 2 (October 22, 2020): 216-29. https://doi.org/10.21009/biosferjpb.v13n2.216-229.

Zhou, Quan, Chei Sian Lee, Sei-Ching Joanna Sin, Sijie Lin, Huijie Hu, and Muhammad Fahmi Firdaus Bin Ismail. "Understanding the Use of YouTube as a Learning Resource: A Social Cognitive Perspective." Aslib Journal of Information Management 72, no. 3 (January 1, 2020): 339-59. https://doi.org/10.1108/AJIM10-2019-0290. 